\title{
Research on Chemical Leakage Based on Three-dimensional Soluble Contaminant Diffusion Model
}

\author{
HONGQIAN ZHANG ${ }^{1}$, YANHUA YANG ${ }^{2}$, , SHAOWU LI ${ }^{1}$, SUHAI KANG $^{2}$ \\ ${ }^{1}$ State Key Laboratory of Hydraulic Engineering Simulation and Safety, Tianjin University \\ ${ }^{2}$ Key Laboratory of Engineering Sediment of Ministry of Transport, Tianjin Research Institute for Water Transport \\ Engineering
}

\begin{abstract}
The leakage and diffusion of pollutants are important issues affecting waters. This paper studies the diffusion of soluble pollutants in water. Based on the three-dimensional hydrodynamic model, a three-dimensional soluble pollutant diffusion model was established and validated. The validation results show that the discrete form of the transport equation used in this model must maintain monotonic properties, and otherwise the model calculation cannot converge. Taking Tianjin Nangang as a representative river section, the cognitive experiment on methanol leakage was carried out to predict the variation characteristics of chemical leakage and diffusion over time in Nangang. The model can be used for chemical leakage and diffusion prediction simulations of other pollutants, and can be used for calculations in runoff and tidal waters.
\end{abstract}

Keywords: Hydrodynamic, three-dimensional, diffusion, Tianjin Nangang, prediction

\section{Introduction}

Water environment pollution is a major environmental issue of great concern today, especially in coastal waters. The diffusion, transport and transformation of pollutants are affected by many factors such as complex dynamic factors, hydro meteorological conditions, boundary factors, biological and chemical effects, so the law of migration and transformation of pollutants is very complicated [1-8]. The most basic function of the water quality model is to simulate and predict the behavior of pollutants in the water environment [9-16]. Contaminants are very complex in the migration process, and the model helps to understand the law of motion of pollutants. Scholars have done a lot of work in this respect [17-28]. Chau established a mathematical model of threedimensional pollutant transport and a coupled solution of water flow model equations, and considering the influence of lateral boundaries, simulated the change of COD water quality in Pearl River [29-36]. Salterain used the four-point implicit scheme difference method to solve the water flow equation and adopted the IWA water quality model [37]. Charafi developed a two-dimensional numerical model to simulate the sediment and pollutant transport in a shallow basin [38]. Liao combined the water quality model with the " $3 \mathrm{~S}$ " geographic information system GIS, the remote sensing system RS, and the global positioning system GPS to pictorially display the spatial characteristics and statistical characteristics of the water quality change of the water flow in the waters [39]. Srinivas used genetic algorithms for water quality prediction [40], and Sharad, Marina, Zhang, et al. employed neural networks for water quality prediction [41-55].

*email: Yang.Jie2019@hotmail.com,yyh200@163.com 
Based on the mathematical model of three-dimensional non-static pressure flow, this paper developed a three-dimensional soluble pollutant diffusion model, and through the example verification, the constraints of the model were studied. Moreover, taking Nangang, Tianjin, China as an example, a typical cognitive mathematical model test of chemical leakage was carried out to simulate the diffusion characteristics of chemical leakage over time in this water area.

\section{Material and methods}

\subsection{Basic Theoretical Equation}

\subsubsection{Basic Governing Equation and Discretization of Hydrodynamic Model}

The basic governing equation is:

$$
\begin{aligned}
& \frac{\partial u}{\partial x}+\frac{\partial v}{\partial y}+\frac{\partial w}{\partial z}=0 \\
& \frac{\partial u}{\partial t}+\frac{\partial u^{2}}{\partial x}+\frac{\partial u v}{\partial y}+\frac{\partial u w}{\partial z}=f v-\frac{1}{\rho} \frac{\partial P}{\partial x}+\frac{\partial}{\partial x}\left(\gamma \frac{\partial u}{\partial x}\right)+\frac{\partial}{\partial y}\left(\gamma \frac{\partial u}{\partial y}\right)+\frac{\partial}{\partial z}\left(\gamma \frac{\partial u}{\partial z}\right) \\
& \frac{\partial v}{\partial t}+\frac{\partial u v}{\partial x}+\frac{\partial v^{2}}{\partial y}+\frac{\partial v w}{\partial z}=-f u-\frac{1}{\rho} \frac{\partial P}{\partial y}+\frac{\partial}{\partial x}\left(\gamma \frac{\partial v}{\partial x}\right)+\frac{\partial}{\partial y}\left(\gamma \frac{\partial v}{\partial y}\right)+\frac{\partial}{\partial z}\left(\gamma \frac{\partial v}{\partial z}\right) \\
& \frac{\partial w}{\partial t}+\frac{\partial u w}{\partial x}+\frac{\partial v w}{\partial y}+\frac{\partial w^{2}}{\partial z}=-g-\frac{1}{\rho} \frac{\partial P}{\partial z}+\frac{\partial}{\partial x}\left(\gamma \frac{\partial w}{\partial x}\right)+\frac{\partial}{\partial y}\left(\gamma \frac{\partial w}{\partial y}\right)+\frac{\partial}{\partial z}\left(\gamma \frac{\partial w}{\partial z}\right)
\end{aligned}
$$

where $u, v, w$ are the components of the velocity vector along the three coordinate axes $\mathrm{x}, \mathrm{y}, \mathrm{z} ; \rho$ is the water body density; $g$ is the gravity acceleration; $P$ is the pressure; $f$ is the Coriolis force coefficient; and $\gamma$ is the eddy viscosity coefficient.

The planar unstructured grid and the vertical layered grid were used to discretize the model equation by the finite volume method combined with the finite difference method; the water level gradient item was discretized by semi-implicit finite difference, the vertical viscosity item was implicitly discretized, the continuity equation was discretized by the finite volume method, the pressure Poisson equation was solved by the method of fractional steps to decompose the pressure item into the hydrostatic pressure and hydrodynamic pressure items to be processed separately, and then the final variable value is solved by pressure correction [52].

\subsubsection{Turbulence Equation and Discretization}

The basic governing equation of hydrodynamic model was closed by a standard $\kappa$ - $\varepsilon$ turbulence model.

The standard $\kappa-\varepsilon$ turbulence model can be expressed as:

$$
\begin{aligned}
& \frac{D k}{D t}-\nabla\left[\frac{v_{t}}{\sigma_{k}} \nabla k\right]=c_{\mu} \frac{k^{2}}{\varepsilon} G-\varepsilon \\
& \frac{D \varepsilon}{D t}-\nabla\left[\frac{v_{t}}{\sigma_{\varepsilon}} \nabla \varepsilon\right]=c_{1} \frac{\varepsilon}{k} G-c_{2} \frac{\varepsilon^{2}}{k}
\end{aligned}
$$


The semi-implicit first-order upwind finite volume method was used to discretize equations (5) and (6). The discretization scheme was mass-conservative and had monotonic conservation properties.

\subsubsection{Material Transport Equation and Discretization}

The conservative material transport equation is:

Where $C$ is the concentration of the transported material (which may be salinity, temperature or sediment, etc.); $K^{h}$ and $K^{v}$ are the horizontal and vertical diffusion coefficients.

The semi-implicit first-order upwind finite volume method was used to discretize equation (7), the discrete scheme was mass-conservative and had monotonic conservation properties.

$$
\frac{\partial C}{\partial t}+\frac{\partial(u C)}{\partial x}+\frac{\partial(v C)}{\partial y}+\frac{\partial(w C)}{\partial z}=\frac{\partial}{\partial x}\left(K^{h} \frac{\partial C}{\partial x}\right)+\frac{\partial}{\partial y}\left(K^{h} \frac{\partial C}{\partial y}\right)+\frac{\partial}{\partial z}\left(K^{v} \frac{\partial C}{\partial z}\right)
$$

\subsection{Model Validation}

The validation of the three-dimensional soluble pollutant diffusion model was carried out in two aspects. Firstly, the hydrodynamic part was verified, and then the transport equation was validated. The hydrodynamic verification was based on the results of the three-dimensional linear standing wave experiment, and the verification of the transport equation was based on the salt water wedge convective diffusion process.

\subsubsection{Three-Dimensional Linear Standing Wave Experimental Verification}

It is assumed that there is a three-dimensional closed pool with the length of 10 meters, width of 10 meters, and depth of more than 10 meters. The initial speed is assumed as zero and the initial water level is:

$$
\eta(x, y)=A \cos \left(k_{x} x\right) \cos \left(k_{y} y\right)
$$

Where the amplitude $A=0.1 \mathrm{~mm}, A / h=0.01 ; K_{x}$ and $K_{y}$ are the wave numbers in the $x$ and $y$ directions, respectively, and $K_{x}=\pi / L, K_{y}=\pi / W$, the total wave number $k=\sqrt{k_{x}^{2}+k_{y}^{2}}=0.44$, and the corresponding wave period $T=3.01 \mathrm{~s}$ (Figure 1).

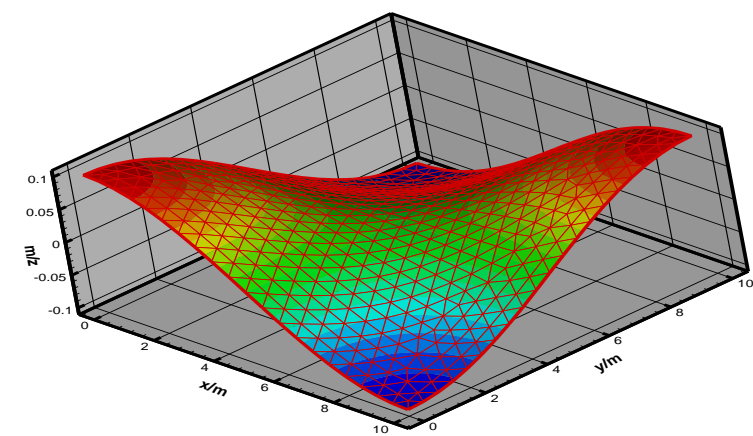

Figure 1. Initial water level in the three-dimensional area

In the numerical calculation, the computational domain is discretized by a triangular unit in the 
plane, and 10 layers are vertically divided, regardless of the viscosity. Figure 2 and Figure 3 show the comparison between the calculation results and the analytical solutions of the water levels at $(x, y)=(0.125,0.125)$ and $(x, y)=(3.625,3.625)$ respectively. It can be seen from the figures that the calculation results are in good agreement with the analytical solutions. Figs. 4, 5 and 6 show the comparison of the calculation results of the speeds $\mathrm{u}, \mathrm{v}$ and $\mathrm{w}$ with the analytical solutions, respectively.

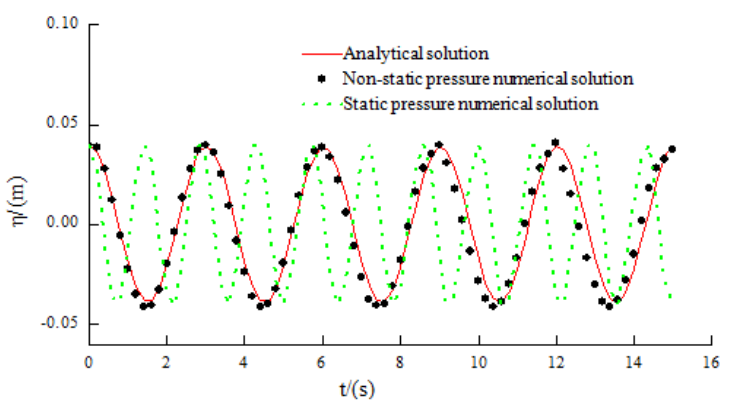

Figure 2. Comparison of numerical and analytical solution of water level at $(x, y)=(0.125,0.125)$

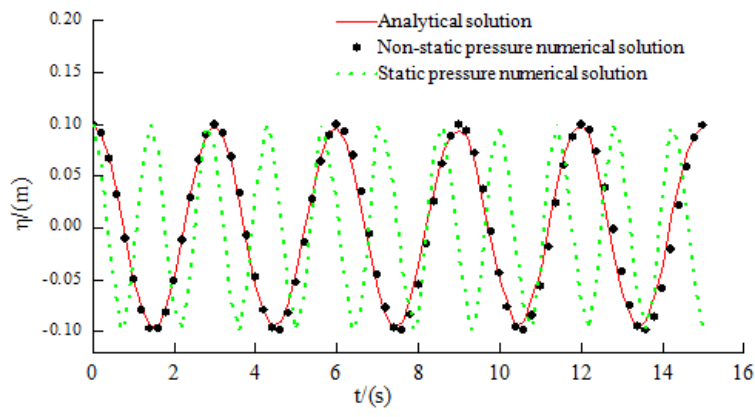

Figure 3. Comparison of numerical and analytical solution of water level at $(\mathrm{x}, \mathrm{y})=(3.625,3.625)$

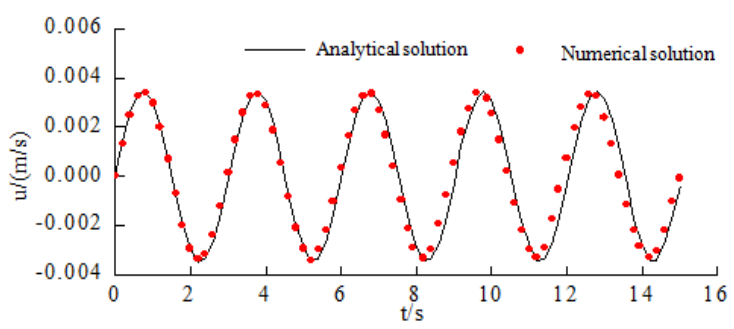

Figure 4. Comparison of numerical and analytical solution of speed $\mathrm{u}$ at $(\mathrm{x}, \mathrm{y}, \mathrm{z})=(3.75,1.125,1.25)$ 


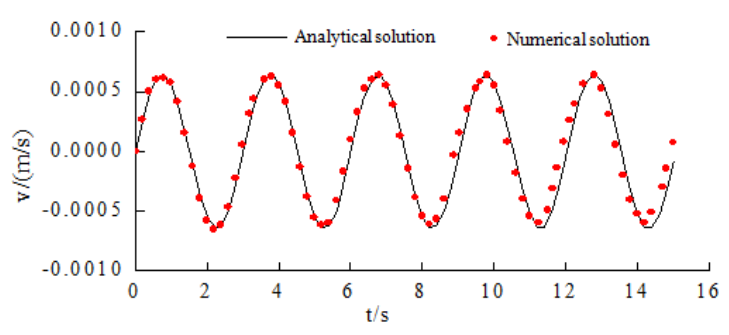

Figure 5. Comparison of numerical and analytical solution of speed $\mathrm{v}$ at $(\mathrm{x}, \mathrm{y}, \mathrm{z})=(3.625,1.25,1.25)$

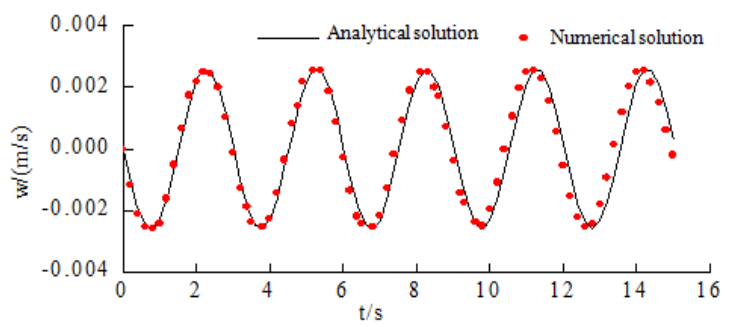

Figure 6. Comparison of numerical and analytical solution of speed $w$ at $(x, y, z)=(3.625,1.25,1.25)$

\subsubsection{Salt Water Wedge Experimental Verification}

There is a vertical infinitely thin retaining dam in the middle of a vertical rectangular area. The salinity on the left side of the dam is $\rho_{1}=1.03$, and the clean water is on right side, i.e. $\rho_{2}=1.0$ (Figure 7). The rectangular area is $L=2 \mathrm{~m}$ long and the water depth is $h=0.3 \mathrm{~mm}$. The horizontal area is covered by a triangular mesh with an average mesh size of $0.02 \mathrm{~m}$, and is divided into 30 layers in the vertical direction. The calculation time step is taken as $\Delta \mathrm{t}=0.01 \mathrm{~s}$. At $=0 \mathrm{~s}$, the retaining dam is suddenly removed, and the calculation results are shown in Figs. 8 and 9. This example is used to verify the discretization of the transport equation. If the discrete form of the transport equation does not have the monotonic conservation properties, this example cannot be calculated at all.

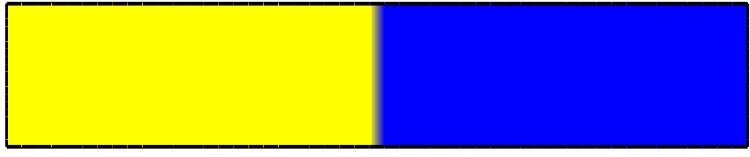

Figure 7. Initial state of the salt water wedge

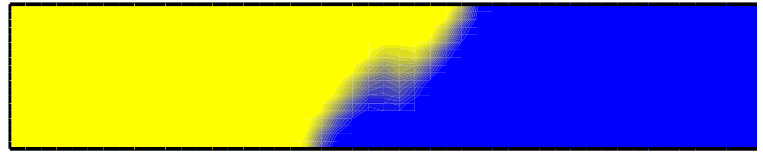

(a) $\mathrm{t}=2 \mathrm{~s}$

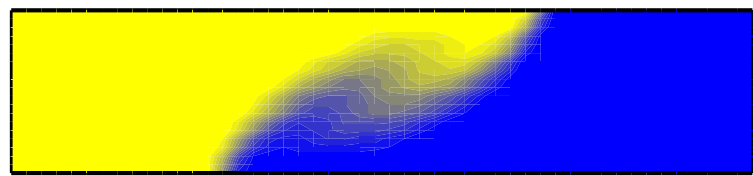

(b) $t=4 s$ 


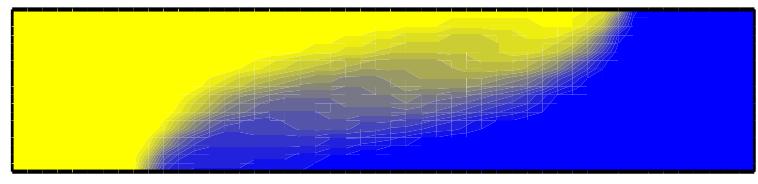

(c) $\mathrm{t}=6 \mathrm{~s}$

Figure 8. Distribution of salinity calculated in the model

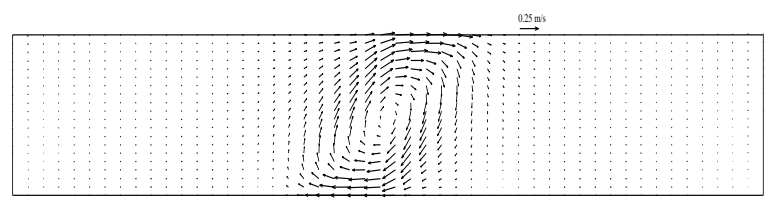

(a) $t=2 s$

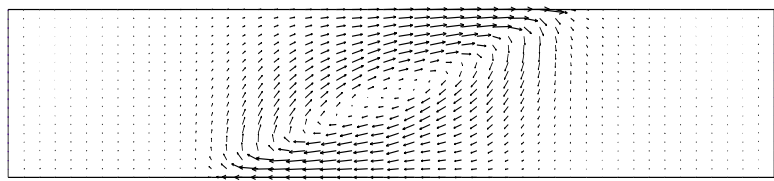

(b) $\mathrm{t}=4 \mathrm{~s}$

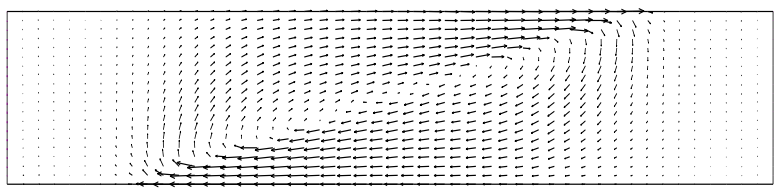

(c) $\mathrm{t}=6 \mathrm{~s}$

Figure 9. Distribution of velocity calculated in the model

\section{Cognitive Experiment on Chemical Leakage Diffusion Prediction}

\subsection{Study Area}

Chemical leakage is predicted in Tianjin Nangang along Bohai Sea, China. The total planning area of Tianjin Nangang Industrial Zone is about $200 \mathrm{~km}^{2}:-4$ meters of bathymetric contour to the east, west to Jinqi Highway, south to the Qingjing Yellow River Right Regulation Line, and north to the Duliujian River Left Regulation Line. Among them, the existing upland area is $38 \mathrm{~km}^{2}$, the land reclamation area is $124 \mathrm{~km}^{2}$, and the water area of the harbor basin channel is $38 \mathrm{~km}^{2}$. According to the planning of Nangang Industrial Zone, there are chemical companies and chemical terminals, so there is a risk of chemical leakage. Once there is leakage of hazardous chemicals at sea, they will rapidly spread to the surrounding areas with the rise and fall of tide. If they are not dealt with quickly, they will seriously affect the aquatic organisms in the polluted waters, causing immeasurable environmental impact. Therefore, it is very important to accurately and timely predict the dynamic diffusion range of pollutants and provide scientific basis for emergency rescue decisionmaking after the accident.

\subsection{Scope of Model}

Considering that Nangang is located in the Bohai Bay and the periphery boundary conditions are difficult to determine, the Bohai Sea is taken as the scope of the entire mathematical model to facilitate the control of the boundary control conditions. The boundary of the control entrance is the line from Dalian $\left(38^{\circ} 52^{\prime} \mathrm{N}, 121^{\circ} 41^{\prime} \mathrm{E}\right)$ to Yantai $\left(37^{\circ} 33^{\prime} \mathrm{N}, 121^{\circ} 23{ }^{\prime} \mathrm{E}\right)$, the model has a total length of 
$8.57 \times 104 \mathrm{~km}^{2}$, as shown in Figure 10. The model has a large calculation range, so the number of grids in the entire calculation domain is controlled by controlling the density of the unstructured grid in the control region and thus to control the overall calculated amount.

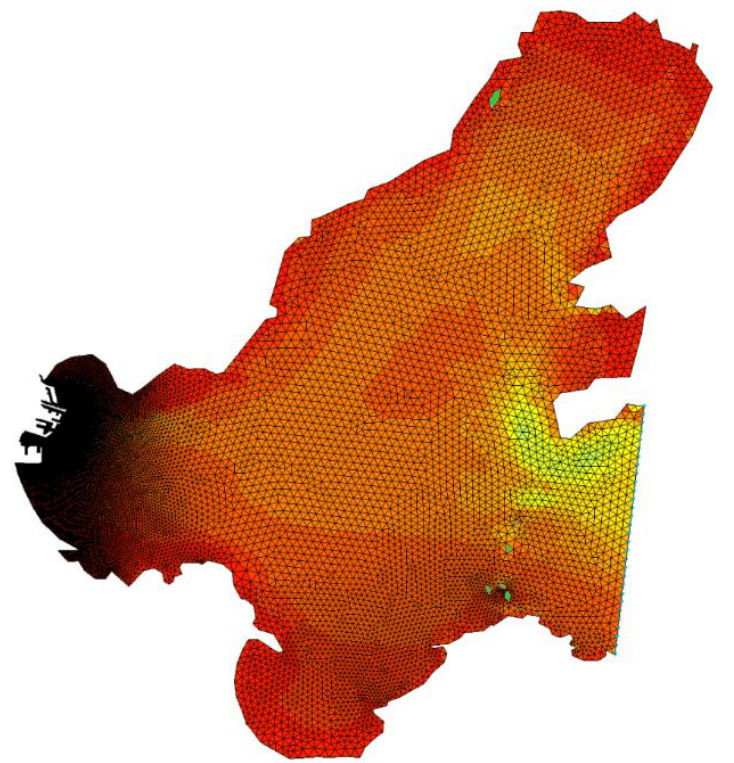

Figure 10. Calculation range of the plane two-dimensional tidal flow mathematical model of the Bohai Sea

\subsection{Model Validation}

There are more important ports along the entire Bohai Sea coast, and each port has accumulated tidal level observation data, which provides a basis for the validation of the model.

\subsubsection{Tidal level validation}

The Tanggu Station near Nangang Port is used as a hydrological station for tidal level verification. The tidal level, flow velocity, and flow direction at the selected different time periods are calculated separately. In each validation calculation, the base surface of tidal level is the local mean sea level (the same below).

It can be seen from Figure 11 that Tanggu Tide Station has been well verified, including the spring tide, moderate tide neap tide in the study area. The calculated results are in good agreement with the predicted values, and the maximum error of the whole process is less than $0.09 \mathrm{~m}$.

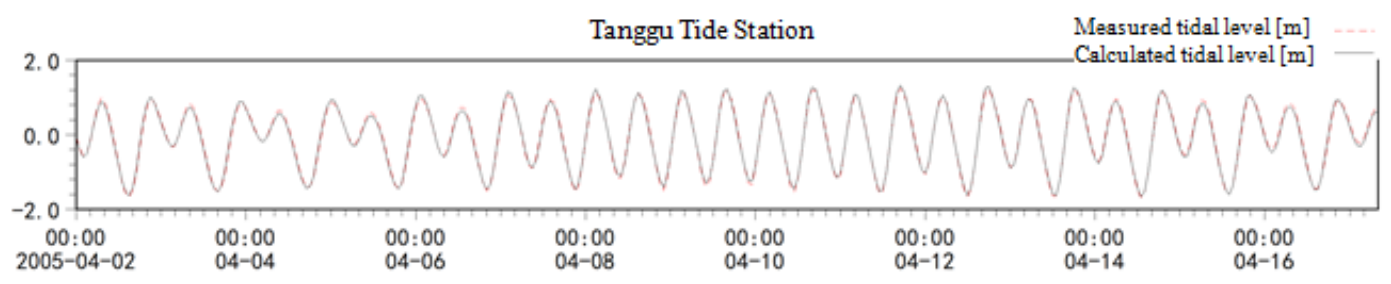

Figure 11. Full-scale tide verification of Tanggu Tide Station 


\subsubsection{Flow Velocity Validation}

Eight stations were set up in the vicinity of Nangang, and a full-scale hydrological test was carried out. The flow velocity and flow direction of the eight stations were measured on site. Figure 12 shows the spring tide velocity verification results of the 1\# and 2\# stations in Nangang District Station. In the figure, "o" is the flow velocity value at the measured tide level, " $\square$ " is the measured flow direction value, the solid line represents the calculation result, and the flow direction angle starts from the magnetic fragmentation north direction for the measurement, and the clockwise direction is positive.

The calculation results of flow velocity and flow direction are in good agreement with the measured data, which can be used to predict the hydrodynamic environment of chemical leakage in the study area.
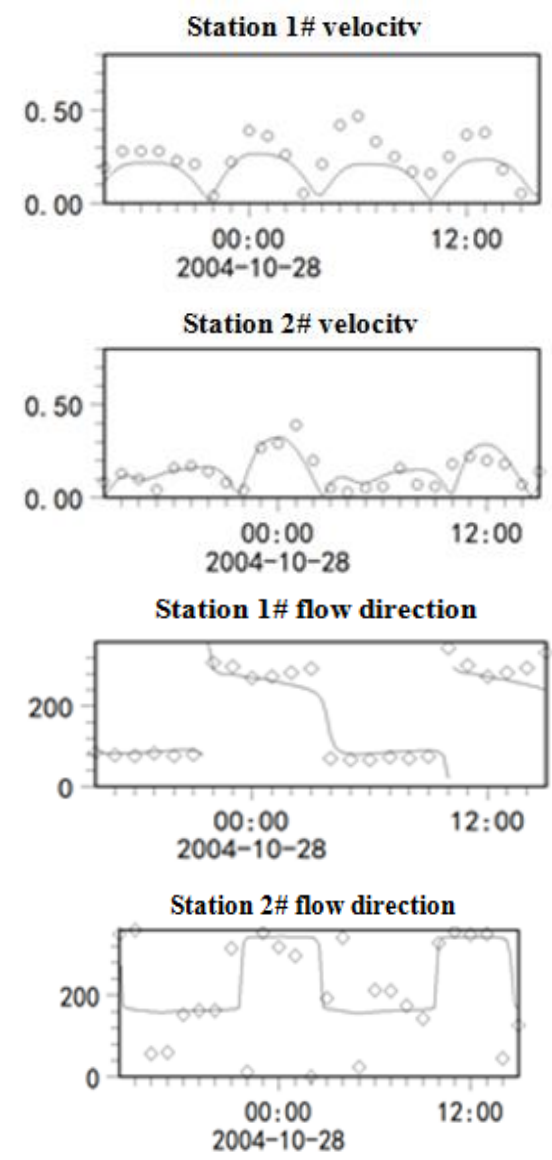

Figure 12. Validation of measured spring tide velocityat stations in Nangang District

\subsubsection{Cognitive Test on Chemical Leakage}

It is assumed that the methanol leakage occurs at the junction of the north exit of the harbor basin at the east side of Nangang and the waterway. The methanol leakage amount is 1 ton within 2 hours, and the specific gravity of the leaked methanol is $0.792 \mathrm{~kg} / \mathrm{m}^{3}$ (100\% purity). According to the known assumptions, the total volume of leaked methanol is $1263 \mathrm{~m}^{3}$, the leakage uniformly performs within 2 hours, and the leak strength is $0.1754 \mathrm{~m}^{3} / \mathrm{s}$. The simulation of the spring tide shape from October 17 to 18,2011 is carried out to simulate the range of convective diffusion 24 hours after the start of the leakage, and the slack moment is chosen as the of the start of the leakage.

Methanol is soluble and the analog computation is carried out according to the standard convection diffusion equation in three dimensions. The calculation of the model is done with three layers vertically. Through the simulation of the mathematical model, the influence range of methanol diffusion with the rise and fall of tide is obtained. Figure 13 shows areal map in which the seawater 
methanol concentration exceeds a certain value at some time after the occurrence of the leakage. The maximum sea area swept by the water body with a concentration higher than $0.01 \mathrm{mg} / \mathrm{l}$ during this period is $13.5 \mathrm{~km}^{2}$. The impact of methanol is mainly limited to the port area where the leak point is located within 24 hours after leakage.

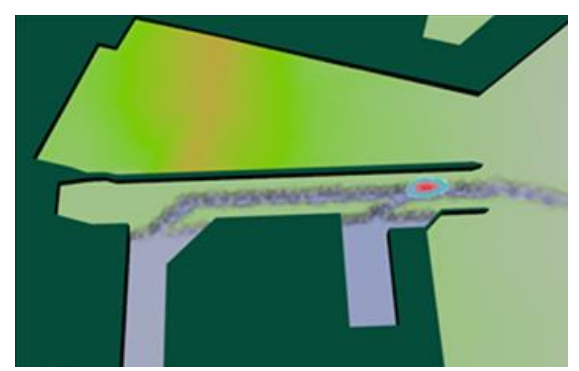

(a) 4.5 hours after the leakage

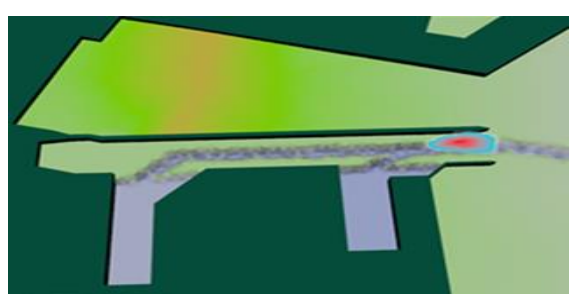

(b) 6 hours after the leakage

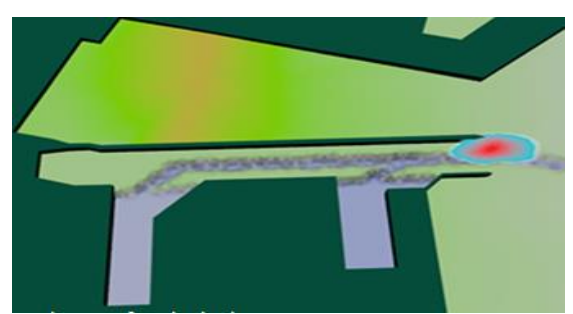

(c) 8 hours after the leakage

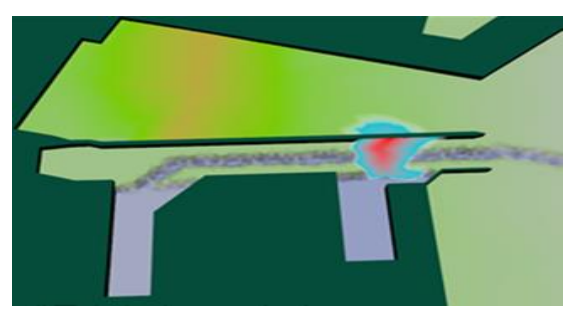

(d) 13.5 hours after the leakage

(e)

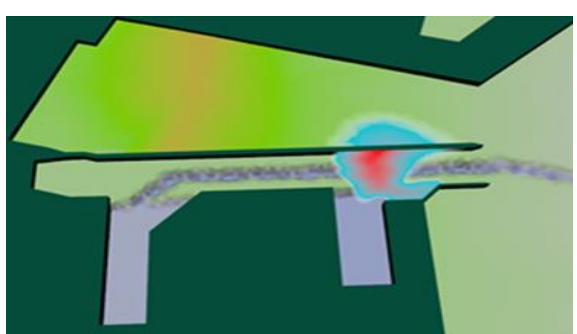

(e) 18 hours after the leakage

Figure 13. Diffusion range several hours after methanol leakage (the minimum concentration is $0.01 \mathrm{mg} / \mathrm{L}$ ) 


\section{Conclusions}

The leakage and spread of pollutants under water conditions such as sea areas are major environmental impact problems in waters. In this regard, this paper developed a chemical leakage model based on the diffusion of three-dimensional soluble pollutants, and the numerical examples were used to study the constraints of the model. Moreover, taking typical waters as an example, the typical cognitive mathematical model test of chemical leakage was carried out to simulate the diffusion characteristics of chemical leakage over time in this water area. The main conclusions are drawn as follows:

(1) Based on the three-dimensional hydrodynamic model, a three-dimensional soluble pollutant diffusion model was established. The three-dimensional model adopts the finite volume method which makes the whole domain strictly satisfy the mass conservation to facilitate the accurate solution of the transport equation. A semi-implicit and step-by-step solution mode is used to establish the threedimensional numerical model with free surface flow. This model can be used for the study of the diffusion of soluble pollutants in sea areas affected by tidal currents.

(2) The three-dimensional soluble pollutant mathematical model was verified from two aspects. Firstly, the hydrodynamic model part was verified in a three-dimensional linear standing wave experiment; and the pollutant diffusion process was then verified using a salt water wedge. The verification results show that the discrete form of the transport equation used in this model must have a monotonic nature.

(3) The three-dimensional soluble pollutant mathematical model was applied in Nangang, Tianjin, China. It is planned to arrange chemical companies and chemical terminals in the Nangang Industrial Zone, so there is a risk of chemical leakage. Taking the Bohai Sea as the scope of the whole mathematical model, a three-dimensional mathematical model was established. The density of the unstructured grid in the region controls the number of grids in the entire computational domain, and thereby controls the total calculated amount. The methanol leakage cognition test shows that the influence of methanol is mainly limited to the port area where the leakage point is located within 24 hours after leakage. The maximum sea area swept by water body with a concentration higher than 0.01 $\mathrm{mg} / \mathrm{l}$ during this period is $13.5 \mathrm{~km}^{2}$.

Acknowledgments: This project is partially supported by National Natural Science Foundation of China (51979132), Central Public Research Institutes Fundamental Research (TKS190405)

\section{References}

1.RAJENDRAN, V., SHRINITHIVIHAHSHINI, N. D., SRINIVASAN B., Quality assessment of pollution indicators in marine water at critical locations of the Gulf of Mannar Biosphere Reserve, Tuticorin. Mar. Pollut. Bull., 126, 2018, 236-240.

2.WANG, H., WANG, J., LU, H., BO, G., ZHANG, X., CAO, Y., LIU, L., ZHANG, J., ZHANG, W., Analysis of coating electrode characteristics in the process of removing pollutants from wastewater. Fresenius. Environ. Bull., 29(2), 2020, 715-721.

3.GUO, J., ZHANG, X., GU, F., ZHANG, H., FAN, Y., Does air pollution stimulate electric vehicle sales? Empirical evidence from twenty major cities in China. J. Clean. Prod., 249, 2020, 1-31.

4.HAIBIN, L., ZHENLING, L., Recycling utilization patterns of coal mining waste in China. Resour. Conserv. Recycl., 54(12), 2010, 1331-1340.

5.WANG, H., AN, X., ZHANG, Z., Effect of advanced treatment on ammonia nitrogen contained in secondary effluent from wastewater treatment plant. Fresenius. Environ. Bull., 27(4), 2018, 20432050.

6.GU, F., GUO, J., ZHANG, W., SUMMERS, P. A., HALL, P., From waste plastics to industrial raw materials: A life cycle assessment of mechanical plastic recycling practice based on a real-world case study. Sci. Total. Environ., 601, 2017, 1192-1207.

7.WANG, M., ZHANG, D., CHENG, Y., TAN, S. K., Assessing performance of porous pavements 
and bioretention cells for stormwater management in response to probable climatic changes. $J$. Environ. Manage., 243, 2019, 157-167.

8.WANG, H., ZHONG, H., BO, G., Existing forms and changes of nitrogen inside of horizontal subsurface constructed wetlands. Environ. Sci. Poll. Res., 25(1), 2018, 771-781.

9.THOMANN, R. V., The future "Golden Age" of predicative models for surface water quality and ecosystem management. J. Environ. Eng., 124(2), 1998, 94-103.

10.CAO, Y., LI, Y., ZHANG, G., JERMSITTIPARSERT, K., NASSERI, M., An efficient terminal voltage control for PEMFC based on an improved version of whale optimization algorithm. Energy Reports, 6, 2020, 530-542.

11.CHENG, Y., SONG, Z., JIN, J., WANG, J., WANG, T., Experimental study on stress wave attenuation and energy dissipation of sandstone under full deformation condition. Arab. J. Geosci., 12(23), 2019, 736-749.

12.ZHU, B., SU, B., LI, Y., Input-output and structural decomposition analysis of India's carbon emissions and intensity, 2007/08-2013/14. App. Energy., 230, 2018, 1545-1556.

13.CAO, Y., WANG, Q., FAN, Q., NOJAVAN, S., JERMSITTIPARSERT, K., Risk-constrained stochastic power procurement of storage-based large electricity consumer. J. Energy. Stor., 28, 2020, 101183-101192.

14.ZHU, B., YE, S., JIANG, M., WANG, P., WU, Z., XIE, R., WEI, Y. M., Achieving the carbon intensity target of China: A least squares support vector machine with mixture kernel function approach. Appl. Energy., 233, 2019, 196-207.

15.JI, Q., GUO, J. F., Oil price volatility and oil-related events: An Internet concern study perspective. Appl. Energy., 137, 2015, 256-264.

16.ZHU, B., SU, B., LI, Y., Input-output and structural decomposition analysis of India's carbon emissions and intensity, 2007/08-2013/14. Applied Energy, 230, 2018, 1545-1556.

17.MAHAJIAN, A. U., CHALAPATIRAO, C. V., Mathematical modeling- a tool for coastal water quality management. Water Sci. Technol., 40(2), 1999, 151-157.

18.HUTCHINSON, C., Uses of satellite data for famine early warning in Sub-Saharam Africa. Int. J. Remote. Sens., 12, 1991, 1405-1421.

19.DE, W. A., Faine early warning systems and the use of socioeconomic data. Disasters., 12, 1988, 81-91.

20.FINNEY, B. A., BOWLES, D. S., WINDHAM, M. P., Random differential equations in river water quality modeling. Water. Resour. Res., 18(1), 1982, 122-134.

21.GU, R., Reservoir flow sensitivity to inflow and ambient parameters. J. Water. Res. Plan. Man., 124(3), 1998, 119-127.

22.KIM, K. W., Verification of a 3D hydrodynamic model of the San Juan Estuary system International. Water. Resour. Engin. Conference-Proceedings., 3, 1998, 1032-1037.

23.WANG, P., LI, J. B., BAI, F. W., LIU, D. Y., XU, C., ZHAO, L., WANG, Z. F., Experimental and theoretical evaluation on the thermal performance of a windowed volumetric solar receiver. Energy, 119, 2017, 652-661.

24.WANG, G., WANG, F., SHEN, F., JIANG, T., CHEN, Z., HU, P., Experimental and optical performances of a solar CPV device using a linear Fresnel reflector concentrator. Renew. Energy., 146, 2020, 2351-2361.

25.WANG, Y., CAO, L., HU, P., LI, B., LI, Y., Model establishment and performance evaluation of a modified regenerative system for a $660 \mathrm{mw}$ supercritical unit running at the IPT-setting mode. Energy, 179, 2019, 890-915.

26.YU, D., ZHU, H., HAN, W., HOLBURN, D., Dynamic multi agent-based management and load frequency control of PV/Fuel cell/wind turbine/CHP in autonomous microgrid system. Energy, 173, 2019, 554-568.

27.ZHU, B., ZHANG, M., HUANG, L., WANG, P., SU, B., WEI, Y. M., Exploring the effect of carbon trading mechanism on China's green development efficiency: A novel integrated approach. 
Energy. Econ., 85, 2020, 1-23.

28.ZHU, B., YE, S., HAN, D., WANG, P., HE, K., WEI, Y. M., XIE, R., A multiscale analysis for carbon price drivers. Energy. Econ., 78, 2019, 202-216.

29.CHAU, K. W., JIANG, Y. W., Simulation of transboundary pollutant transport action in the Pearl River delta. Chemosphere., 52(9), 2003, 1615-1621.

30.ZENG, L., CHEN, G., CHEN, H., Comparative Study on Flow-Accelerated Corrosion and Erosion-Corrosion at a $90^{\circ}$ Carbon Steel Bend. Materials, 13(7), 2020, 1780-1796.

31.LIU, Z., FENG, J., WANG, J., Resource-Constrained Innovation Method for Sustainability: Application of Morphological Analysis and TRIZ Inventive Principles. Sustainability, 12(3), 2020, 917-939.

32.QUAN, Q., HAO, Z., XIFENG, H., JINGCHUN, L., Research on water temperature prediction based on improved support vector regression. Neur. Comp. App., 2020, 1-10.

33.GUO, J., PAN, J., GUO, J., GU, F., KUUSISTO, J., Measurement framework for assessing disruptive innovations. Technol. Forecast. Soc. Change., 139, 2019, 250-265.

34.CHEN, H., FAN, D., HUANG, J., HUANG, W., ZHANG, G., HUANG, L., Finite Element Analysis Model on Ultrasonic Phased Array Technique for Material Defect Time of Flight Diffraction Detection. Sci. Adv. Mater., 12(5), 2020, 665-675.

35.LIU, Y. X., YANG, C. N., SUN, Q. D., WU, S. Y., LIN, S. S., CHOU, Y. S., Enhanced embedding capacity for the SMSD-based data-hiding method. Signal Processing: Image. Commun., 78, 2019, 216-222.

36.GU, F., GUO, J., YAO, X., SUMMERS, P. A., WIDIJATMOKO, S. D., HALL, P., An investigation of the current status of recycling spent lithium-ion batteries from consumer electronics in China. J. Clean. Prod., 161, 2017, 765-780.

37.SALTERAIN, A., Development and verification of a new simulation tool for water quality prediction in the Ebro river progress in water resource. Water. Pollut., 9, 2003, 13-22.

38.CHARAFI, M. Y. M., SADOK, A., KAMAL, A., MENAI, A., Numerical modeling of water circulation and pollutant transport in a shallow basin. Int. J. Mod. Phys. C., 11(4), 2000, 655-664.

39.LIAO, H., TIM, U. S., An interactive modeling environment for Non-point source pollution control. J. Am. Water. Resour. As., 33(3), 1997, 591-603.

40.SRINIVAS, M., PATNAIK, L. M., Adaptive probability of crossover and mutation in genetic algorithm. IEEE Trans on SMC, 24(4), 1994, 656-667.

41.SHARAD, K. J., Development of integrated sediment rating curves using ANNs. J. Hydraul. Eng., 127(1), 2001, 30-37.

42.MARINA, C., Forecasting river flow rate during low-flow period using neural network. Water Resour. Res., 35(11), 1999, 3547-3552.

43.ZHANG, B., Prediction of water runoff using B ayesian concepts and modular neural network. Water. Resour. Res., 36(3), 2000, 753-762.

44.GU, F., MA, B., GUO, J., SUMMERS, P. A., HALL, P., Internet of things and Big Data as potential solutions to the problems in waste electrical and electronic equipment management: An exploratory study. Waste. Manage., 68, 2017, 434-448

45.LEI, Z., JIHAO, C., ZHANG, L., HUIBIN, H., YUSU, W., YONGHUI, L., Preparation of soybean oil factory sludge catalyst and its application in selective catalytic oxidation denitration process. $J$. clean. Prod., 225, 2019, 220-226.

46.ZHANG, T., WU, X., SHAHEEN, S. M., ZHAO, Q., LIU, X., RINKLEBE, J., REN, H., Ammonium nitrogen recovery from digestate by hydrothermal pretreatment followed by activated hydrochar sorption. Chem. Eng. J., 379, 2020, 1-54.

47.LIU, X., ZHOU, X., ZHU, B., HE, K., WANG, P., Measuring the maturity of carbon market in China: an entropy-based TOPSIS approach. J. clean. Prod., 229(1), 2019, 94-103.

48.LEI, Z., GAO, H., CHANG, X., ZHANG, L., WEN, X., WANG, Y., An application of green surfactant synergistically metal supported cordierite catalyst in denitration of Selective Catalytic 
Oxidation. J. Clean. Prod., 249, 2020, 1-26.

49.ZHU, B., ZHOU, X., LIU, X., WANG, H., HE, K., WANG, P., Exploring the risk spillover effects among China's pilot carbon markets: A regular vine copula-CoES approach. J. Clean. Prod., 242, 2020, $1-7$.

50.CAO, L., TU, C., HU, P., LIU, S., Influence of solid particle erosion (SPE) on safety and economy of steam turbines. Appl. Therm. Eng., 150, 2019, 552-563

51.LEI, Z., YANG, J., HUIBIN, H., CHAO, Y., MIN, L., LINTIAN, M., Preparation of soybean oil factory sludge catalyst by plasma and the kinetics of selective catalytic oxidation denitrification reaction. J. clean. Prod., 217, 2019, 317-323.

52.YANG, Y. H., KANG, S. H., KANG, Z. F., LIU, X. Q., LI, X. X., Oil Spill at Sea Based on Nonhydrostatic Three-dimensional Hydrodynamic Mathematical Model. Desalin. Water. Treat., 122, 2018, 298-303.

53.ZHU, B., MA, S., XIE, R., CHEVALLIER, J., WEI, Y. M., Hilbert spectra and empirical mode decomposition: A multiscale event analysis method to detect the impact of economic crises on the European carbon market. Comput. Econ., 52(1), 2018, 105-121.

54.JIANG, M., ZHU, B., CHEVALLIER, J., XIE, R., Allocating provincial CO2 quotas for the Chinese national carbon program. Aust. J. Agri. Resour. Econ., 62(3), 2018, 457-479.

55.CHEN, H., HUANG, L., YANG, L., CHEN, Y., HUANG, J., Model-based method with nonlinear ultrasonic system identification for mechanical structural health assessment. Trans. Emerge. Telecommun. Technol., 2020. https://doi.org/10.1002/ett.3955

$\overline{\text { Manuscript receivd: } 24.04 .2020}$ 